Provided for non-commercial research and education use. Not for reproduction, distribution or commercial use.

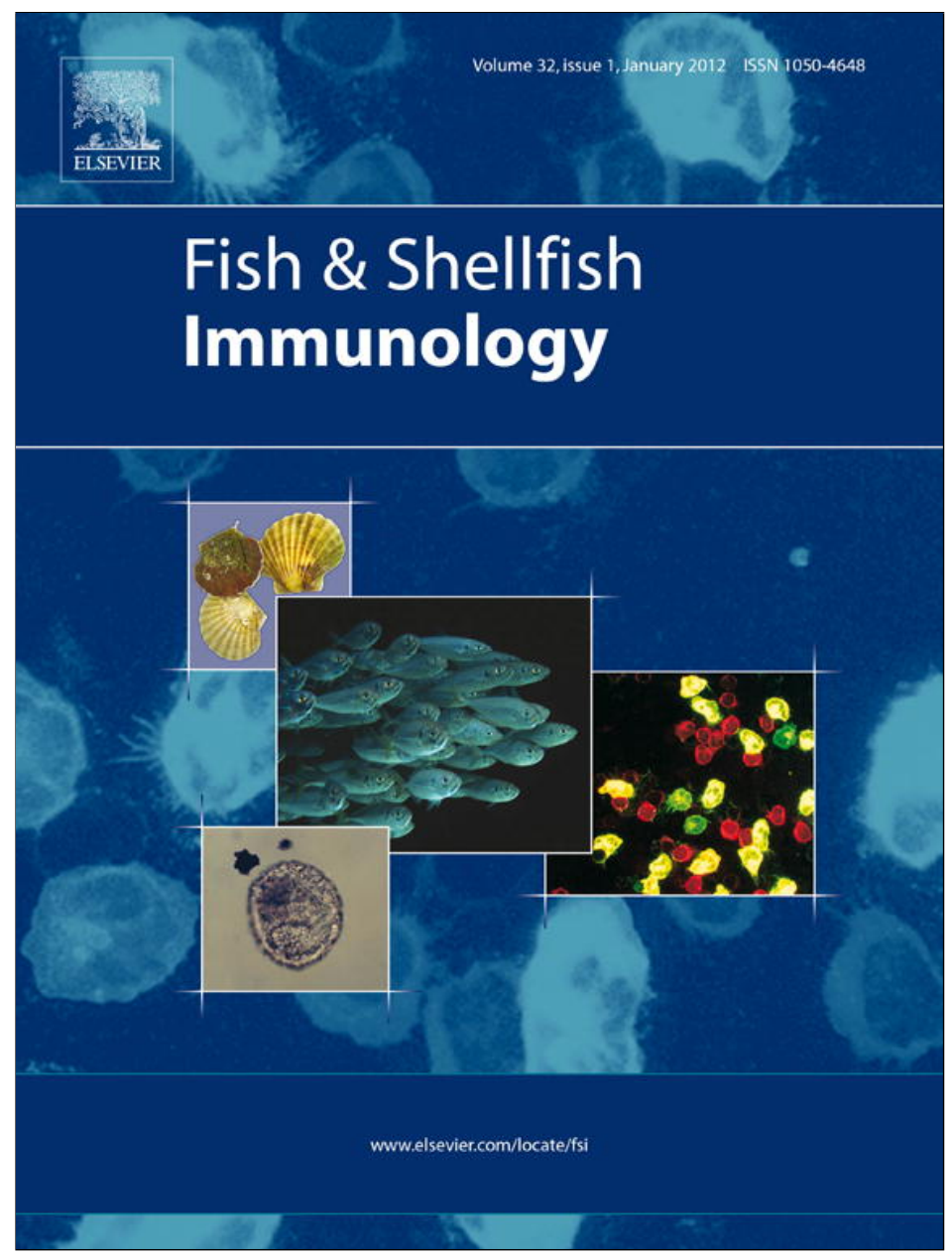

This article appeared in a journal published by Elsevier. The attached copy is furnished to the author for internal non-commercial research and education use, including for instruction at the authors institution and sharing with colleagues.

Other uses, including reproduction and distribution, or selling or licensing copies, or posting to personal, institutional or third party websites are prohibited.

In most cases authors are permitted to post their version of the article (e.g. in Word or Tex form) to their personal website or institutional repository. Authors requiring further information regarding Elsevier's archiving and manuscript policies are encouraged to visit:

http://www.elsevier.com/copyright 


\title{
Gene expression specificity of the mussel antifungal mytimycin (MytM)
}

\author{
Molruedee Sonthi ${ }^{a}$, Franck Cantet ${ }^{\mathrm{a}, 1}$, Mylène Toubiana ${ }^{\mathrm{a}}$, Maria-Rosa Trapani ${ }^{\mathrm{b}}$, Maria-Giovanna Parisi ${ }^{\mathrm{b}}$, \\ Matteo Cammarata ${ }^{\mathrm{b}}$, Philippe Roch ${ }^{\mathrm{a}, *}$ \\ ${ }^{a}$ Ecologie des Systèmes Marins et Côtiers (EcoSym), Université Montpellier 2-CNRS, cc 093, place E. Bataillon, F-34095 Montpellier cedex 05, France \\ ${ }^{\mathrm{b}}$ Marine Immunobiology Laboratory, University of Palermo, Via Archirafi 18, 90123 Palermo, Italy
}

\section{A R T I C L E I N F O}

\section{Article history:}

Received 25 August 2011

Received in revised form

13 October 2011

Accepted 14 October 2011

Available online 24 October 2011

\section{Keywords:}

Antifungal peptide

Q-PCR

Innate immunity

Challenge

Specificity

\begin{abstract}
A B S T R A C T
We previously reported the nucleotide sequences and diversity of mytimycin (MytM) from the Mediterranean mussel, Mytilus galloprovincialis. Using real-time PCR (q-PCR), we observed that the MytM gene was mainly expressed in circulating hemocytes and to a less extent in the mantle. In vivo challenge with bacteria or with the yeast, Candida albicans, did not increase the expression as measured by q-PCR in hemocytes. By contrast, injection of the filamentous fungus, Fusarium oxysporum, induced a sudden and strong increase of expression at $9 \mathrm{~h}$ p.i. (stimulation index of $25.7 \pm 2.1$ ). Optimum stimulating dose was $10^{4}$ spores of $F$. oxysporum per mussel. In the same samples, AMP mytilin and myticin showed no stimulation. Consequently, we hypothesized the existence of 2 different signal transduction pathways, one activated by bacteria and yeast, the other triggered by filamentous fungi. A second challenge performed with $F$. oxysporum $24 \mathrm{~h}$ after the first challenge induced an increase of MytM gene expression (stimulation index of $3.5 \pm 1.7$ ). However, this second increase was significantly lower than the first, suggesting less efficient response rather than significant protection.
\end{abstract}

(c) 2011 Elsevier Ltd. All rights reserved.

\section{Introduction}

Mytimycin (MytM), the first strictly antifungal protein from mollusks, has been partially identified from the blue mussel, Mytilus edulis, in 1996 using biochemical techniques and Sanger's sequencing [7]. Recently, we isolated 16 nucleotide sequences related to MytM from a M. galloprovincialis EST library [37] and established the full cds of the precursor [34]. It possesses the same construction as other antibacterial peptides: defensin, mytilin and myticin, i.e. a signal peptide followed by the mature MytM of 54 aa, and a C-terminal extension. In addition, 2 major deduced aa precursor sequences were observed, one shared by the mussels from Venice-Italy and Vigo-Spain, the other belonged to those mussels from Palavas-France. Predicted disulfide bonds of these 12 cysteine peptides suggested the presence of 2 constrained domains [34]. Recently, a partial 47 aa (no cysteine) antifungal peptide, but

Abbreviations: aa, amino acids; AMP, antimicrobial peptide; cds, coding sequence; EST, expressed sequence tags; MytM, mytimycin; nt, nucleotides; p.i, post-injection; q-PCR, quantitative or real-time PCR.

* Corresponding author. Tel.: +33 4671447 12; fax: +33 467144673.

E-mail address: Philippe.Roch@univ-montp2.fr (P. Roch).

1 Present address: Centre d'études d'agents Pathogènes et Biotechnologies pour la Santé (CPBS), CNRS-UM 1-UM 2, 1919 route de Mende, F-34293 Montpellier cedex 05, France. sharing also a weak effect on bacteria, has been isolated from a native Chilean scallop, Argopecten purpuratus, and used as framework to design substitutes for conventional antibiotics [2].

Occurrence of antifungal molecules and their induction have been reported in insects. In Drosophila, the antifungal cysteine-rich drosomycin [15] is strongly up regulated by fungal infection, mediated by the Toll pathway, and only slightly by the Imd pathway [26] Antibacterial attacin and cecropin genes are activated by fungi and bacteria, as well as metchnikowin, which is also antifungal ([20]). By contrast, strictly antibacterial diptericin and drosocin genes are mainly activated by Gram-negative bacteria through the Imd pathway [19]. Another inducible antifungal peptide, but also active against Gram-positive and Gram-negative bacteria, thanatin, has been isolated from the insect, Podisus maculiventris [14].

Fusarium oxysporum, a diploid filamentous fungus widely distributed in soil and water, was reported as having an extremely broad host range. Although responsible for only opportunistic infections in immune depressed humans, pathogenic activity was particularly frequent toward insects [17] and crustaceans [13,23] through the production of various toxins. F. oxysporum has been used in antimicrobial assays in shrimp [11] and mussels [29].

Candida albicans, a diploid fungus or yeast, is the most common human fungal pathogen. It is normally a harmless commensally organism, but it can be an opportunistic pathogen responsible for painful mucosal infections. Although not considered as an 
important contaminant of seawater, C. albicans is frequently detected in the Mediterranean Sea [25]. According to the European Union Bathing Water Standards based on the presence of enterococci, $35 \%$ of the waters classified as "good" and 39\% of the "excellent" contained $C$. albicans, confirming its extended repartition [12]. In an experimental assay, C. albicans survived at least 52 weeks in seawater, with no effect of salinity but a strong negative effect of elevated temperature with a survival limited to 5-6 weeks at $35{ }^{\circ} \mathrm{C}$ [1]. In addition, C. albicans was reported from all sites sampled in a rain forest freshwater stream and in near-shore coastal tropical waters of Puerto-Rico [35]. Not only in water was C. albicans detected, but also in oysters and mussels particularly during the colder months [4] revealing its possible transmission to humans through the consumption of seafood.

Beta-glucans are polysaccharide chains of D-glucose monomers linked by beta type glycoside bonds. They constitute the major structural components of cell wall from the yeast, Saccharomyces cerevisiae. Due to their capacity to enhance the innate immune system [8], they are extensively used as feed additives for cultivated crustaceans, resulting in increased survival in ponds [6]. In our study, $\beta$-glucans preparation has been used to replace intact yeast in the assays for regulating MytM gene expression.

In the present report, we established by q-PCR (i) the comparative expression of MytM gene in various tissues, (ii) the optimum dose-effect of filamentous fungus $F$. oxysporum spores, (iii) the specificity of induction by comparing the responses to $F$. oxysporum with $C$. albicans, $\beta$-glucans and bacteria injections, (iv) the response of antimicrobial peptide mytilin and myticin genes in fungal challenged mussels, and ( $\mathrm{v}$ ) measured MytM gene expression after a second challenge.

\section{Material and methods}

\subsection{Mussels and fungi}

Adult mussels, Mytilus galloprovincialis (6-7 cm shell length), were purchased from the marine farm Les Compagnons de Maguelone (Palavas-France) out of the reproduction period. They were acclimated for $24-48 \mathrm{~h}$ in the laboratory airlift system of oxygenated re-circulating seawater at $20{ }^{\circ} \mathrm{C}$ before challenge. Filamentous fungus, F. oxysporum, and yeast, C. albicans, were a gift from Prof. Alain Clérivet (IUT Département Génie Biologique, Montpellier-France). They were allowed to grow on 1.5\% agar PDA (Potatoes Dextrose Agar, Sigma-Aldrich) in Petri dishes incubated at room temperature in the dark. After 2-4 days, the dishes were washed with phosphate buffered solution isotonic to seawater (PBS-NaCl: $2 \mathrm{mM} \mathrm{KH} \mathrm{HPO}_{4}, 10 \mathrm{mM} \mathrm{Na} \mathrm{HPO}_{4}, 3 \mathrm{mM} \mathrm{KCl}, 600 \mathrm{mM}$ $\mathrm{NaCl}$ in distilled water, $\mathrm{pH}$ 7.4). The collected liquid was filtered through cotton wool and the spore number adjusted to $2 \times 10^{5} / \mathrm{ml}$ with PBS-NaCl. Beta-glucans containing $\beta-(1 \rightarrow 3)$ and $\beta-(1 \rightarrow 6)$ components, were from baker's yeast $S$. cerevisiae (Sigma). They were diluted in PBS- $\mathrm{NaCl}$ as a stock solution of $330 \mu \mathrm{g} / \mathrm{ml}$.

\subsection{In vivo challenges, RNA extraction and reverse transcription}

Routine challenges with fungi consisted of one injection of $2 \times 10^{4}$ spores in $100 \mu \mathrm{l} \mathrm{PBS}-\mathrm{NaCl}$ into the posterior adductor muscle. Challenge with $\beta$-glucans consisted of one injection of $100 \mu \mathrm{l}$ of PBS- $\mathrm{NaCl}$ containing $33 \mu \mathrm{g}$ of $\beta$-glucans into the posterior adductor muscle. After injection, mussels were returned to seawater at $20^{\circ} \mathrm{C}$. cDNAs from mussels challenged with bacteria were from Li et al [22]. Briefly, mussels from Palavas-France were challenged by one injection of $10^{7}$ Vibrio splendidus LGP32, Vibrio anguillarum (Gram-) or Micrococcus lysodeikticus (Gram+) into the posterior adductor muscle and returned to seawater at $20^{\circ} \mathrm{C}$.
Hemolymph was collected from the posterior adductor muscle with a $1 \mathrm{ml}$ syringe containing $0.2 \mathrm{ml}$ of the anti-coagulant modified Alsever's solution buffer, before challenge (UC) and 1, 3, 6, 9, 12 , 24, 48 and 72 h post-injection (p.i.). Hemolymph from 10 mussels per time point was pooled and hemocytes pelleted by $15 \mathrm{~min}$ centrifugation at $800 \mathrm{~g}, 4^{\circ} \mathrm{C}$. To analyze constitutive expression in tissues, hemolymph was collected, and gills, hepatopancreas, mantle, muscle and foot were dissected from 5 unchallenged mussels and pooled. For dose-effect responses, 10 mussels per dose were injected with $100 \mu \mathrm{l}$ of PBS- $\mathrm{NaCl}$ containing $0,10^{2}, 10^{3}, 10^{4}$ and $10^{5}$ spores of $F$. oxysporum and hemolymph collected at 9 h p.i. For second challenge assays, 10 mussels per end point were injected with $10^{4}$ spores of $F$. oxysporum, and then re-injected $24 \mathrm{~h}$ later with $10^{4}$ spores of $F$. oxysporum. Hemolymph was collected as above and all experiments have been repeated 4 times.

Total RNA was extracted using the Trizol Reagent protocol (Invitrogen). Quantity of RNA was evaluated by spectrophotometer using NanoDrop ND-1000 (NanoDrop Technologies). Quality was assayed by electrophoresis using Agilent RNA Nano LabChip (Agilent Technologies). First strand cDNA synthesis was performed on $1 \mu \mathrm{g}$ of total RNA using random primers (Promega) and murine leukemia virus reverse transcriptase (Promega), and kept in nuclease-free water at $-20{ }^{\circ} \mathrm{C}$ until use.

\subsection{Quantitative $P C R(q-P C R)$}

Primers for house keeping gene 28S rRNA, mytilin and myticin mRNA quantifications were from previous report [5]. Mytimycin primers were F2 $\left({ }^{5 \prime}\right.$-GTGTTGTCATTGGCATGGCG $\left.{ }^{3 \prime}\right)$ and R2 $\left({ }^{5 \prime}\right.$ TCGTCCATGATTGACCAATG ${ }^{3}{ }^{3 \prime}$ ) giving a unique amplicon of $367 \mathrm{nt}$ with a melting temperature of $82.34 \pm 0.08{ }^{\circ} \mathrm{C}$. q-PCR was performed using the SYBR Green chemistry on a LightCycler $480 \times 384$ well-plate (Roche Diagnostics) as previously reported [21] with $1 \mu \mathrm{M}$ of each primer and $65{ }^{\circ} \mathrm{C}$ of hybridization temperature.

Gene expression levels were quantified by the Livak $\left(2^{-\Delta \Delta \mathrm{CT}}\right)$ method using the ratio of equivalent target amount (ETA) for the considered gene on ETA for $28 \mathrm{~S}$ rRNA. Internal reference of $28 \mathrm{~S}$ expression was measured in each time point as recommended [10]. Normalization of the ratios was calculated considering each ratio equal to 1 in unchallenged mussels and expressed as $\mathrm{x}$-fold the ratio for unchallenged mussels. Results were expressed as the arithmetic mean of 3-4 different experiments \pm SD. Statistical analyses for low numbers of assays, used the Mann-Whitney test $(P<0.05)$.

\section{Results}

\subsection{Expression pattern in tissues}

As measured by q-PCR, the presence of MytM mRNA in gills, hepatopancreas, muscle and foot appeared marginal (Fig. 1). Clearly hemocytes had the highest content of MytM mRNA, a level significantly different from all other tissues $(p<0.001)$. Only in the mantle was there a noticeable expression, about 6 times higher than in gills, but significantly lower when compared to hemocytes $(p=0.003)$. Consequently, further quantification of MytM gene expression will be restricted to hemocytes.

\subsection{Dose-effect response of F. oxysporum}

Increasing quantities of spores were injected into mussels and the expression of MytM gene measured at $9 \mathrm{~h}$ p.i. (Fig. 2). In PBSinjected mussels, as well as in mussels injected with lower spore concentrations $\left(10^{2}\right.$ and $\left.10^{3}\right)$, no significant changes in expression were observed. In contrast, injecting higher doses resulted in 


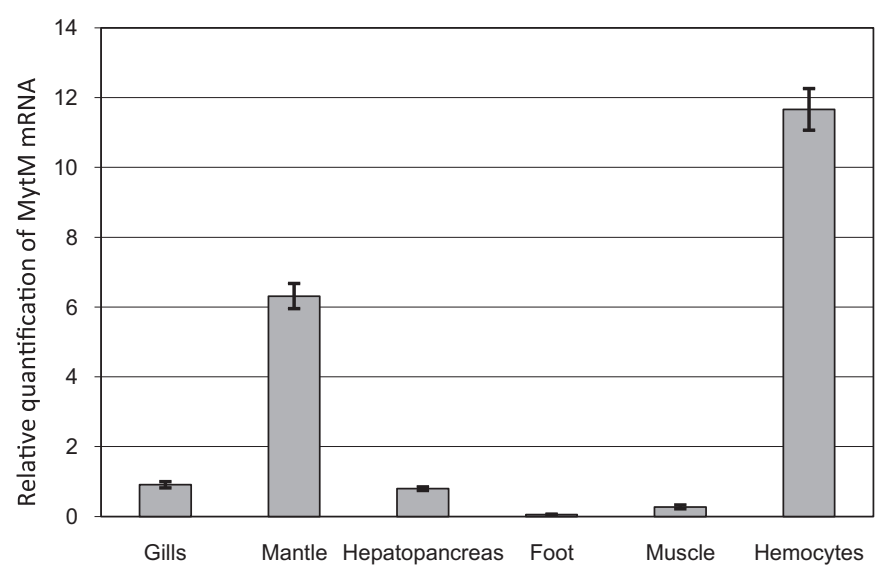

Fig. 1. Quantification of MytM mRNA in various tissues expressed as the mean of $2^{-\Delta \Delta c p}$ for 3 to 4 different samples related to $28 \mathrm{~S}$ mRNA \pm SD (bars). Note the largest expression in hemocytes, a value significantly different from mantle $(p=0.003)$ and from gills, hepatopancreas, muscle and foot $(p<0.001)$.

significantly elevated expression. Such increase was $12.6 \pm 2.9$ folds that of those unchallenged ( $p=0.0004)$ with $10^{4}$ spores and was still significantly higher with $10^{5}$ spores $(2.1 \pm 0.02$ folds, $p=0.02)$.

\subsection{Specificity of regulation}

Kinetics and specificity of the induction of MytM gene expression were investigated in pools of mussels injected with bacteria previously obtained for other experiments ([22]). In mussels injected with different bacteria ( $V$. splendidus, $V$. anguillarum and Micrococcus lysodeikticus), no significant changes in expression were observed (Fig. 3). Similarly, injection of the yeast, C. albicans, did not increase the expression of MytM gene. By contrast, injection of spores from the filamentous fungus, $F$. oxysporum, resulted in a rapid and significant up-regulation of MytM gene expression peaking suddenly at $9 \mathrm{~h}$ p.i., with a stimulation index of $25.7 \pm 2.1$ folds the expression in unchallenged $(p<0.001)$. Later, the intensity of MytM gene expression decreased gradually, but was still

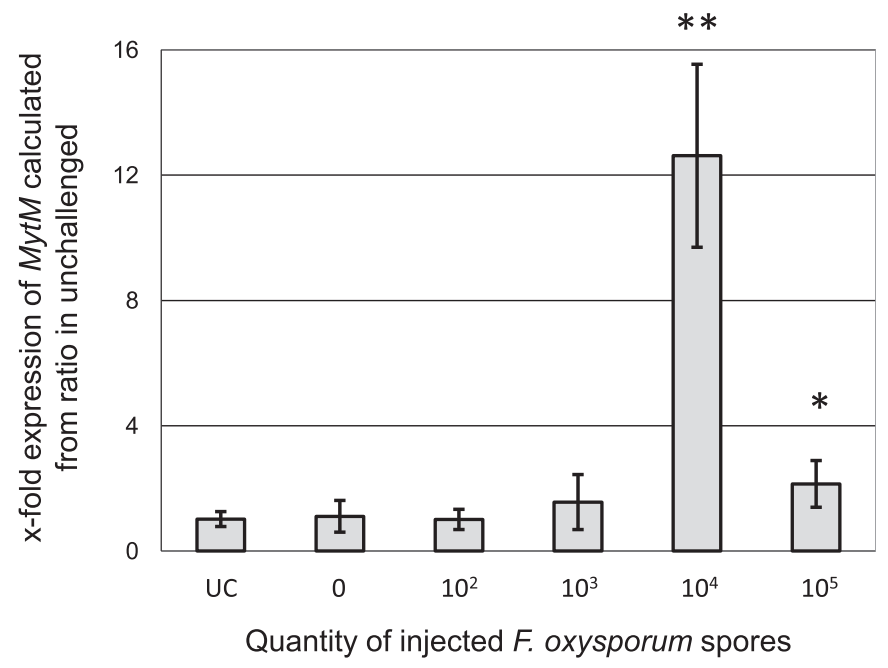

Fig. 2. Dose-effect response of MytM gene expression following one injection of $100 \mu \mathrm{l}$ of PBS- $\mathrm{NaCl}(0)$ alone, or containing various quantities of $F$. oxysporum spores. Data are from 3 to 4 pools of 10 mussels each per injected quantity, measured by q-PCR and expressed as multiplicand factors related to expression in unchallenged (UC) \pm SD (bars). Note the strongest up-regulation observed with $10^{4}$ spores. *: $p<0.05$; **: $p<0.001$.
$7.3 \pm 0.2$ folds at $48 \mathrm{~h}$ p.i. $(p=0.006)$. The highest stimulation observed at $9 \mathrm{~h}$ was statistically significantly different from that observed at $12 \mathrm{~h}(11.6 \pm 1.0, p<0.001)$. Injection of $\beta$-glucans induced a discrete increase of MytM gene expression only after $48 \mathrm{~h}$ $(4.2 \pm 1.4)$ but significantly different from expression in unchallenged $(p=0.01)$.

Specificity of the MytM gene response was investigated measuring the kinetics of expression of the antimicrobial peptide (AMP) genes, mytilin and myticin, in the fungi injected mussels (Fig. 4). Maximum stimulation index was $3.1 \pm 0.4$ (myticin induced by $F$. oxysporum at $48 \mathrm{~h}$ ), the only observed significantly different up-regulation $(p=0.002)$. All other indices were below 2.4 , and insignificantly different from unchallenged, regardless of stimulation or the time p.i.

\subsection{Response to a second challenge}

Mussels were re-injected with $F$. oxysporum $24 \mathrm{~h}$ after the first, and MytM gene expression measured between 1 and $72 \mathrm{~h}$ after this second challenge (Fig. 5). Significant up-regulation was observed at $9 \mathrm{~h}$ after the first injection $(14.0 \pm 1.4, p<0.001$ compared to unchallenged). This confirmed that the new batch of mussels reacted as it had been previously observed (Fig. 3). Consequently, and based on Fig. 3 data, we considered that expression at $24 \mathrm{~h}$ returned to baseline. Second challenge performed $24 \mathrm{~h}$ after the first one resulted in up-regulation measured at $9 \mathrm{~h}(3.5 \pm 1.7$, $p=0.03$ compared to unchallenged) and lasted at least $72 \mathrm{~h}$ ( $4.0 \pm 0.8, p<0.001$ compared to unchallenged). Meanwhile, the kinetics observed following first and second challenge were different. Compared to Fig. 3, no peaking occurred at $9 \mathrm{~h}$ and the average stimulation index of only 3.5 was maintained until $72 \mathrm{~h}$, when the first stimulation gradually decreased and returned to baseline at 24 and $72 \mathrm{~h}$. In addition, the stimulation index recorded $9 \mathrm{~h}$ after the second challenge was statistically significantly different $(p=0.001$ ) from the stimulation index measured after the first challenge.

\section{Discussion}

Used for decades, extracts from fungal cell walls containing $\beta$ glucans have been found to trigger various immune defense mechanisms in plants, invertebrates and even vertebrates. Effect of $\beta$-glucans on immune mechanisms of invertebrates was reviewed in 2004 involving insects, crayfish, shrimp and earthworms [38]. However, the role of $\beta$-glucans on AMP induction was poorly investigated. Only cecropin, one of the Drosophila AMPs, is induced by $\beta$-glucans in hemocytes in vitro ([33]). In the mussel M. galloprovincialis, $\beta$-glucans exert no effect on antibacterial activity, but increased the in vitro production of nitric oxide and the release of free oxygen radicals by hemocytes [24]. By contrast, the same authors reported that hemolymph collected from Ruditapes decussatus injected with $\beta$-glucans, inhibited the growth of $V$. splendidus, Vibrio alginolyticus and E. coli. Unfortunately, the active moiety was not identified.

In a previous report we analyzed the diversity of MytM mRNA purified from hemocytes [34]. In the present work, we quantified such mRNA in several tissues. Clearly hemocytes had the highest content, i.e. more than 10 times higher than in gills. Considered as an immune molecule, is it not surprising that MytM gene is expressed mainly in hemocytes, which represent the most active immune cells of mussels. The mantle also contained noticeable MytM gene expression, but half the expression in circulating hemocytes. Detectable expression at least in the mantle and gills probably resulted from hemocyte infiltration as we reported for defensin, mytilin, and myticin mRNAs [30]. 

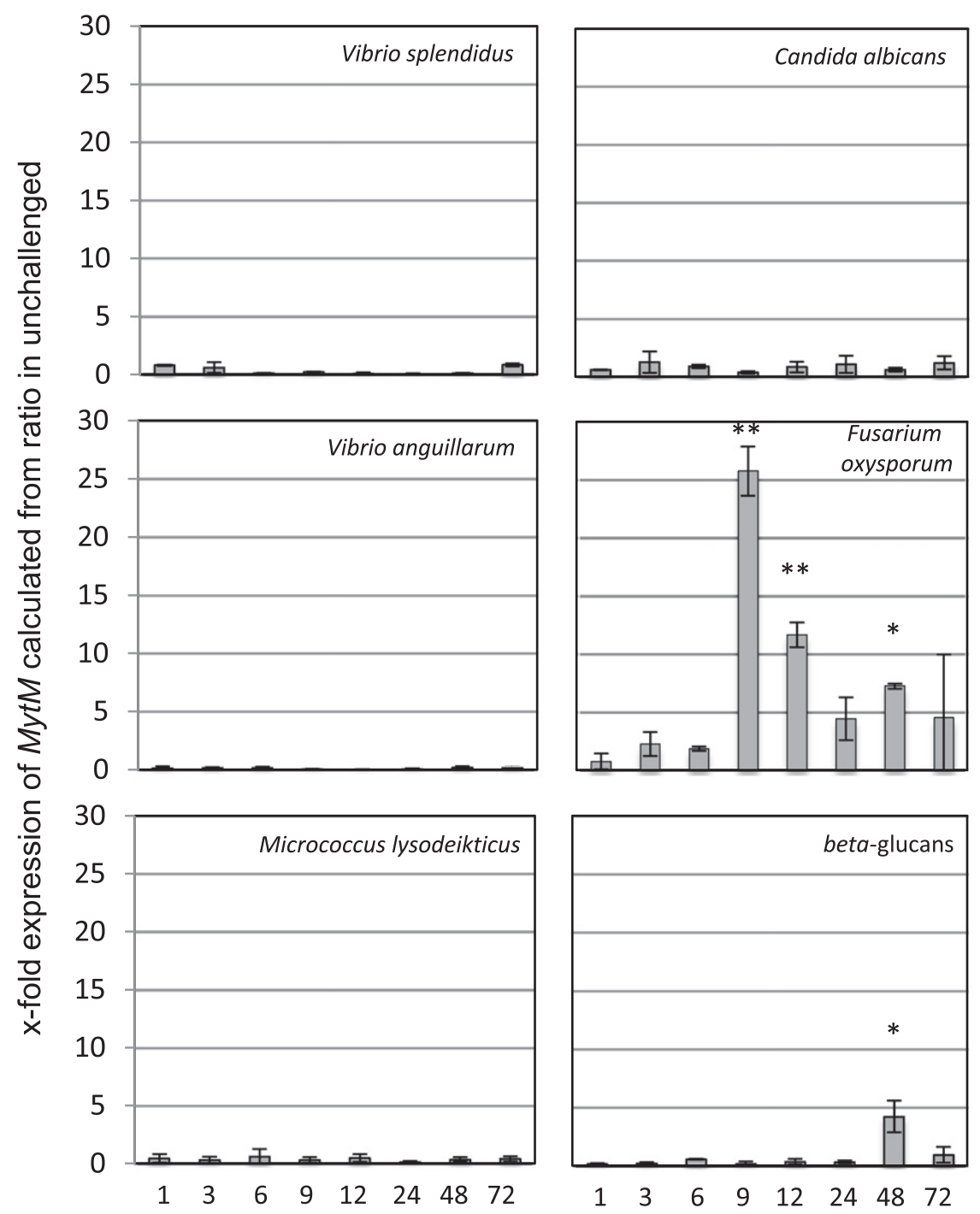

Hours post-injection

Fig. 3. Kinetics of MytM gene expression in response to one injection of Gram-negative ( $V$. splendidus, V. anguillarum), and Gram-positive ( $M$. lysodeikticus) bacteria compared to one injection of yeast (C. albicans), filamentous fungus (F. oxysporum) and fungal cell wall extract (beta-glucans). Data are from 3 to 4 pools of 10 mussels each per end point, measured by q-PCR and expressed as multiplicand factors related to expression in unchallenged \pm SD (bars). *: $p<0.05 ;{ }^{* *}: p<0.001$. Note the strongest up-regulation observed with F. oxysporum.

Mussel defensin, mytilin and myticin shared antibacterial and antifungal properties. In fact, the so-called antifungal activity has been tested only against filamentous fungi: Neurospora crassa for M. edulis [7] and F. oxysporum for M. galloprovincialis [31]. Challenge with Gram-positive M. lysodeikticus resulted in general down regulations of AMP gene expression [5]. Gram-negative challenge effect was more complex with rapid up-regulation (from 1 to $24 \mathrm{~h}$ ) of defensin by $V$. splendidus, to late up regulation (from 1 to 3 days) of mytilin by $V$. anguillarum. In another study, the 3 AMPs were reported as down regulated by all challenging bacteria whatever geographic origin of the mussels [22], confirming previous observations done from 6 to $72 \mathrm{~h}$ [28]. Assays through microarray devoted to $M$. galloprovincialis immunome revealed a general down-regulation of AMP genes following challenges with $V$. splendidus, and particularly MytM with relative expression of -3.02 compared to unchallenged at $48 \mathrm{~h}$ [37]. In the present report, only the filamentous fungus, $F$. oxysporum, strongly stimulated expression of MytM gene. Stimulation appeared suddenly $9 \mathrm{~h}$ after injection, suggesting that a delay is required for recognition and signal transduction. Later, over expression gradually decreased, but was still significantly different from those unchallenged after $48 \mathrm{~h}$. In contrast to induction of AMP gene expressions observed in Drosophila [16], no significant up-regulation of MytM gene was observed with the yeast, $C$. albicans, revealing that the two fungi induced different gene responses.

Injection of $\beta$-glucans, representing soluble extracts of the fungus cell wall, did not modify MytM gene expression, excepted a limited up-regulation observed at $48 \mathrm{~h}$. Significant different responses to spores compared to soluble extracts suggested that stimulation requires solid particles. In fact, internalization by hemocytes is achieved by different mechanisms according to the size of the foreign body: pinocytosis for soluble particles, phagocytosis for solid ones. Therefore, it is hypothesized that triggering of MytM gene resulted from phagocytosis, a receptor-mediated endocytosis, requiring specific recognition. In addition, mussel innate immune system clearly discriminates between filamentous 


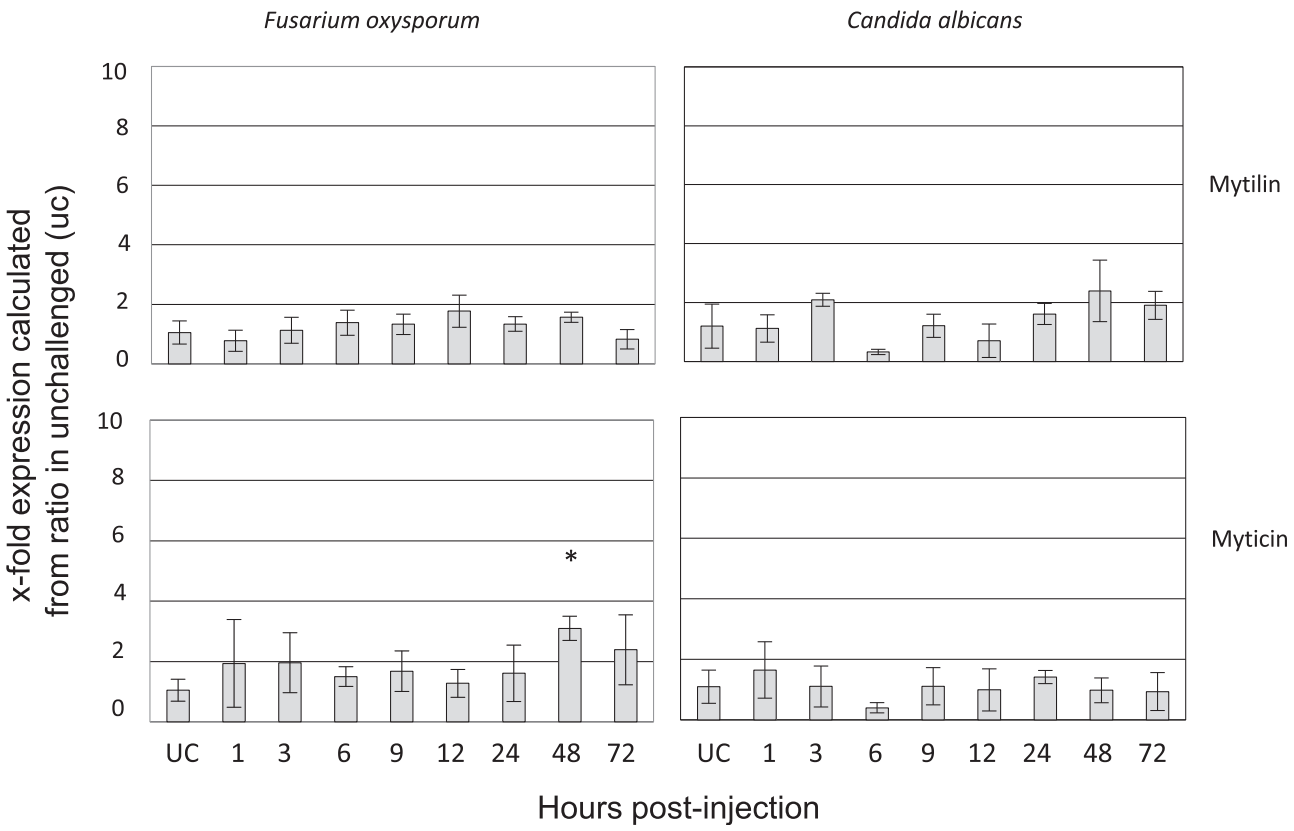

Fig. 4. Kinetics of expression of the AMP mytilin and myticin genes in response to one injection of the filamentous fungus (F. oxysporum) and of the yeast ( $C$. albicans). Data are from 3 to 4 pools of 10 mussels each per end point, measured by q-PCR and expressed as multiplicand factors related to expression in unchallenged \pm SD (bars). ${ }^{*}: p<0.05$. Note the absence of stimulation higher than 3.1, the only statistically significantly different from unchallenged.

and yeast spores, the latest not modifying expression. As they are of similar sizes $(6-9 \mu \mathrm{m}$ for oval-spherical microconidia of F. oxysporum versus $2-7 \times 3-8 \mu \mathrm{m}$ for ovoïd blastoconidia for C. albicans), the different behaviors may result from differences in cell wall composition.

We demonstrated herein that injection of bacteria did not stimulate expression of the MytM gene. Whatever the Gram coloration, bacterial cell wall composition is different from the fungal. As MytM has been reported as strictly antifungal [7], one can hypothesize that its gene expression will depend on the recognition of specific fungal cell wall component(s), if presented in

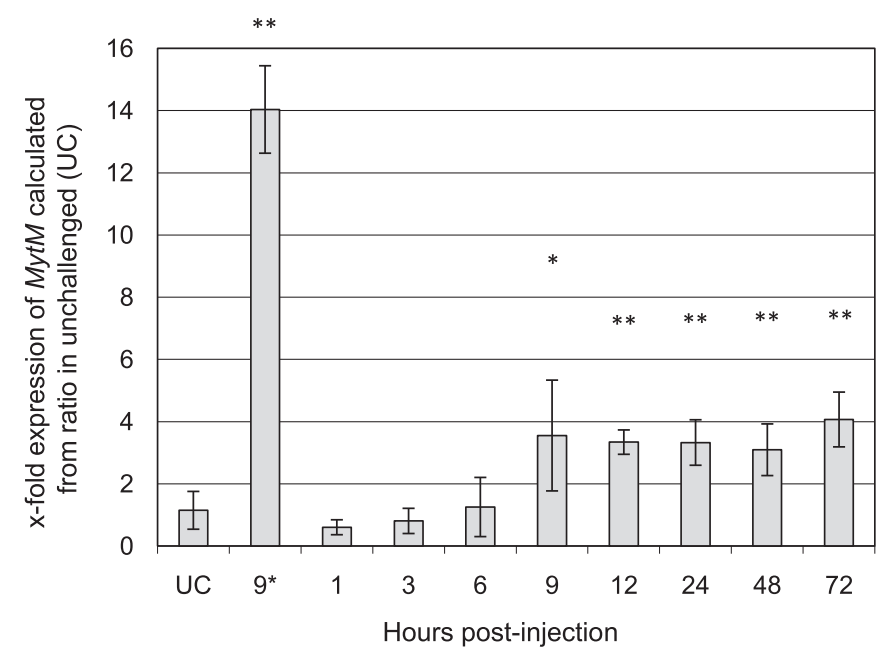

Fig. 5. Kinetics of MytM gene expression in response to a second injection of $F$. oxysporum performed $24 \mathrm{~h}$ after the first challenge. Data are from 4 pools of 10 mussels each, measured in quadriplicate by q-PCR and expressed as multiplicand factors related to expression in unchallenged (UC) \pm SD (bars). 9*: expression measured $9 \mathrm{~h}$ after the first challenge; 1 to 72 : expressions measured after the second challenge; *: $p<0.05 ;{ }^{* *} p<0.001$. Note the significant but lower expression $9 \mathrm{~h}$ after the second challenge compared to the first challenge. a solid form, and might use a different signal transduction pathway, as demonstrated for drosomycin [27]. Either mytilin or myticin genes were not up regulated by fungal challenge. Joined to the fact that bacterial challenges do not trigger MytM gene expression, this observation strongly suggests the existence of different recognition mechanisms or signal transduction pathways in mussels. This suggestion based on functional observations is reinforced by previous report on the putative presence of several MyD88 transcripts, including a Toll/IL-1 receptor domain, in the Zhikong scallop, Chlamys farreri [32], in the Manila clam, Ruditapes philippinarum [18] and in M. galloprovincialis hemocytes [37]. Existence of different signal transduction pathways is well documented in insects where the Toll pathway is engaged in antifungal defense, whereas the Imd pathway triggers different array of antimicrobial peptides [9]. Existence of these two pathways remains to be established in mollusks.

Immune memory in invertebrates is a controversial concept. We suggested that one way to resolve the debate might be to quantify the expression of particular genes or immune effectors following a first and a second challenge [3]. Surprisingly, reports of such studies are rare and based on unusual host-parasite associations, and no one regarding bivalves. With the actual technology to precisely quantify the expression of thousands of genes, it becomes possible to investigate the memory concept in invertebrates. Regarding mussels, we reported herein the expression of the sole MytM gene following a second challenge performed at a time the first response was lowered: no more rapid or intense response was noticed. By contrast, the second response to F. oxysporum challenge was significantly lower than the first suggesting a less efficient response more than a better protection and arguing against memory. It must be underlined that, to avoid additional stress, rechallenged mussels were not the ones sampled to control the stimulation at $9 \mathrm{~h}$. We speculated that all the mussels up regulated at $9 \mathrm{~h}$, returning to background of expression at $24 \mathrm{~h}$, before the second challenge. Although individual variability exists among mussels, we hoped to exclude this bias by measuring 4 pools of 10 mussels each, as previously validated [5]. 
In conclusion, different responses according to different challenges suggested the existence of two signal transduction pathways, one activated by bacteria and yeast, the other triggered by filamentous fungi. Evidences of these two pathways might be obtained by screening Mytibase [36] looking for intermediate molecules similar to the ones known in insects.

\section{Acknowledgments}

This work was partially funded by the EU program BIVALIFE (KBBE-2010-266157), the PICS CNRS n 5197 with the University of Palermo-Italy, and the INTERLINK program from the Italian Ministry of Education. MS was supported by Burapha University from Thailand. Authors are grateful to Alain Clérivet for providing the fungi, to Romain Gros for technical assistance and to Prof Edwin L. Cooper (UCLA) for critical reading and editing the manuscript.

\section{References}

[1] Anderson JH. In vitro survival of human pathogenic fungi in seawater. Sabouraudia 1979;17:1-12.

[2] Arenas G, Guzman F, Cardenas C, Mercado L, Marshall SH. A novel antifungal peptide designed from the primary structure of a natural antimicrobial peptide purified from Argopecten purpuratus hemocytes. Peptides 2009;30: 1405-11.

[3] Brehélin M, Roch P. Specificity, learning and memory in the innate immune response. Invertebr Surv J 2008;5:103-9.

[4] Buck JD, Bubucis PM, Combs TJ. Occurrence of human-associated yeasts in bivalve shellfish from Long Island Sound. Appl Environ Microbiol 1977;33: 370-8.

[5] Cellura C, Toubiana M, Parrinello N, Roch P. Specific expression of antimicrobial peptide and HSP70 genes in response to heat-shock and severa bacterial challenges in mussels. Fish Shellfish Immunol 2007;22:340-50.

[6] Chang CF, Su MS, Chen HY, Liao IC. Dietary beta-1,3-glucan effectively improves immunity and survival of Penaeus monodon challenged with white spot syndrome virus. Fish Shellfish Immunol 2003;15:297-310.

[7] Charlet M, Chernysh S, Philippe H, Hetru C, Hoffmann JA, Bulet P. Innate immunity. Isolation of several cysteine-rich antimicrobial peptides from the blood of a mollusc, Mytilus edulis. J Biol Chem 1996:271:21808-13.

[8] Dalmo RA, Bogwald J. Beta-glucans as conductors of immune symphonies. Fish Shellfish Immunol 2008;25:384-96.

[9] De Gregorio E, Spellman PT, Tzou P, Rubin GM, Lemaitre B. The Toll and Imd pathways are the major regulators of the immune response in Drosophila. EMBO J 2002:21:2568-79.

[10] De Santis C, Smith-Keune C, Jerry DR. Normalizing RT-qPCR data: are we getting the right answers? An appraisal of normalization approaches and internal reference genes from a case study in the Finfish Lates calcarifer. Mar Biotechnol (NY) 2011;13:170-80.

[11] Destoumieux D, Bulet P, Loew D, Van Dorsselaer A, Rodriguez J, Bachere E. Penaeidins, a new family of antimicrobial peptides isolated from the shrimp Penaeus vannamei (Decapoda). J Biol Chem 1997;272:28398-406.

[12] Efstratiou MA, Tsirtsis G. Do 2006/7/EC European Union Bathing water Standards exclude the risk of contact with Salmonella or Candida albicans? Mar Pollut Bull 2009;58:1039-44

[13] Egusa S, Ueda T. A Fusarium sp. associated withblack gill diseases of the kir uma prawn, Penaeus japonicus Bate. Bull Jpn Soc Scientific Fish 1972;38: 1253-60.

[14] Fehlbaum P, Bulet P, Chernysh S, Briand JP, Roussel JP, Letellier L, et al. Structure-activity analysis of thanatin, a 21-residue inducible insect defense peptide with sequence homology to frog skin antimicrobial peptides. Proc Natl Acad Sci U S A 1996;93:1221-5.

[15] Fehlbaum P, Bulet P, Michaut L, Lagueux M, Broekaert WF, Hetru C, et al. Insect immunity. Septic injury of Drosophila induces the synthesis of a potent antifungal peptide with sequence homology to plant antifungal peptides. J Biol Chem 1994;269:33159-63.

[16] Glittenberg MT, Kounatidis I, Christensen D, Kostov M, Kimber S, Roberts I, et al. Pathogen and host factors are needed to provoke a systemic host response to gastrointestinal infection of Drosophila larvae by Candida albicans. Dis Model Mech 2011;4:515-25.

[17] Hasan S, Vago C. The pathogenicity of Fusarium oxysporum to mosquito larvae. J Invertebr Pathol 1972;20:268-71.

[18] Lee Y, Whang I, Umasuthan N, De Zoysa M, Oh C, Kang DH, et al. Characterization of a novel molluscan MyD88 family protein from manila clam, Ruditapes philippinarum. Fish Shellfish Immunol; 2011.

[19] Lemaitre B, Reichhart JM, Hoffmann JA. Drosophila host defense: differential induction of antimicrobial peptide genes after infection by various classes of microorganisms. Proc Natl Acad Sci U S A 1997;94:14614-9.

[20] Levashina EA, Ohresser S, Bulet P, Reichhart JM, Hetru C, Hoffmann JA Metchnikowin, a novel immune-inducible proline-rich peptide from Drosophila with antibacterial and antifungal properties. Eur J Biochem 1995; 233:694-700.

[21] Li H, Parisi MG, Toubiana M, Cammarata M, Roch P. Lysozyme gene expression and hemocyte behaviour in the Mediterranean mussel, Mytilus galloprovincialis, after injection of various bacteria or temperature stresses. Fish Shellfish Immunol 2008;25:143-52.

[22] Li H, Venier P, Prado-Alvarez M, Gestal C, Toubiana M, Quartesan R, et al. Expression of Mytilus immune genes in response to experimental challenges varied according to the site of collection. Fish Shellfish Immunol 2010;28: 640-8.

[23] Lightner DV, Fontaine CT. A mycosis of the American lobster, Homarus americanus, caused by Fusarium sp. J Invertebr Pathol 1975;25:239-45.

[24] Mar Costa M, Novoa B, Figueras A. Influence of beta-glucans on the immune responses of carpet shell clam (Ruditapes decussatus) and Mediterranean mussel (Mytilus galloprovincialis). Fish Shellfish Immunol 2008;24:498-505.

[25] Mates A. Quantitative determination of Candida albicans in sea water Microbios 1994;79:27-30.

[26] Medzhitov R, Janeway Jr CA. Self-defense: the fruit fly style. Proc Natl Acad Sci U S A 1998;95:429-30.

[27] Medzhitov R, Preston-Hurlburt P, Kopp E, Stadlen A, Chen C, Ghosh S, et al. MyD88 is an adaptor protein in the hToll/IL-1 receptor family signaling pathways. Mol Cell 1998;2:253-8.

[28] Mitta G, Hubert F, Dyrynda EA, Boudry P, Roch P. Mytilin B and MGD2, two antimicrobial peptides of marine mussels: gene structure and expression analysis. Dev Comp Immunol 2000a;24:381-93.

[29] Mitta G, Hubert F, Noel T, Roch P. Myticin, a novel cysteine-rich antimicrobia peptide isolated from haemocytes and plasma of the mussel Mytilus galloprovincialis. Eur J Biochem 1999;265:71-8.

[30] Mitta G, Vandenbulcke F, Noel T, Romestand B, Beauvillain JC, Salzet M, et al. Differential distribution and defence involvement of antimicrobial peptides in mussel. J Cell Sci 2000b;113(15):2759-69.

[31] Mitta G, Vandenbulcke F, Roch P. Original involvement of antimicrobial peptides in mussel innate immunity. FEBS Lett 2000c;486:185-90.

[32] Oiu L, Song L, Yu Y, Xu W, Ni D, Zhang O. Identification and characterization of a myeloid differentiation factor 88 (MyD88) cDNA from Zhikong scallop Chlamys farreri. Fish Shellfish Immunol 2007;23:614-23.

[33] Samakovlis C, Asling B, Boman HG, Gateff E, Hultmark D. In vitro induction of cecropin genes-an immune response in a Drosophila blood cell line. Biochem Biophys Res Commun 1992:188:1169-75.

[34] Sonthi M, Toubiana M, Pallavicini A, Venier P, Roch P. Diversity of coding sequences and gene structures of the antifungal peptide mytimycin (MytM) from the Mediterranean mussel, Mytilus galloprovincialis. Mar Biotechno (NY) 2011;13:857-67.

[35] Valdes-Collazo L, Schultz AJ, Hazen TC. Survival of Candida albicans in tropical marine and fresh waters. Appl Environ Microbiol 1987;53:1762-7.

[36] Venier P, De Pitta C, Bernante F, Varotto L, De Nardi B, Bovo G, et al. MytiBase: a knowledgebase of mussel (M. galloprovincialis) transcribed sequences. BMC Genomics 2009;10:72.

[37] Venier P, Varotto L, Rosani U, Millino C, Celegato B, Bernante F, et al. Insights into the innate immunity of the Mediterranean mussel Mytilus galloprovincialis. BMC Genomics 2011;12:69.

[38] Vetvicka V, Sima P. Beta-glucan in invertebrates. Invertebr Surv J 2004;1: $60-5$. 